\title{
Gaston Bachelard e a educação: por uma pedagogia da formação
}

\author{
Gaston Bachelard and education: for a pedagogy of formation
}

\section{Gaston Bachelard y la educación: por una pedagogía de la formación}

\author{
Tairone Lima de Sousa ${ }^{1}$ \\ iD http://orcid.org/0000-0003-0233-834X \\ André Ferrer Pinto Martins ${ }^{2}$ \\ https://orcid.org/0000-0001-7719-5043
}

\begin{abstract}
Resumo: A epistemologia de Gaston Bachelard critica as formas tradicionais de ensino ao entender a educação com o sentido de formação, defendendo uma formação permanente dos sujeitos. Esse sentido de formação, no pensamento bachelardiano, percorre as duas vertentes da sua obra - a científica e a poética - ressaltando a impreterível necessidade da vivência do real e do irreal para a formação do sujeito. É por um processo copioso de desiludir-se, retificar os erros e afastar os obstáculos que Bachelard entende a formação permanente do homem, que nunca se apresenta a priori objetivo, mas com um passado de erros retificados. Nesse contexto, o presente trabalho tem como objetivo avaliar as contribuições da epistemologia de Gaston Bachelard para o campo da educação, destacando a ideia de uma pedagogia científica no ensino como fundamento para o desenvolvimento e a formação de um novo espírito científico, contrapondo-se às formas tradicionais de ensino. Para tanto, situamos o pensamento de Gaston Bachelard dentro do contexto acadêmico-filosófico-cultural francês, apontando os principais conceitos de sua epistemologia, e analisamos as contribuições do pensamento bachelardiano para o campo da educação, sinalizando o porquê da necessidade de uma pedagogia nova no ensino, defendida pelo autor. Esse estudo parte do pressuposto de que a epistemologia de Gaston Bachelard tem um "fundo pedagógico" ainda pouco explorado, expresso quando o autor destaca o "aspecto pedagógico" que as noções científicas carregam. É uma pesquisa de natureza teórica sobre a obra do filósofo francês, assumindo a forma de uma pesquisa bibliográfica.
\end{abstract}

Palavras-chave: Gaston Bachelard. Pedagogia Científica. Formação.

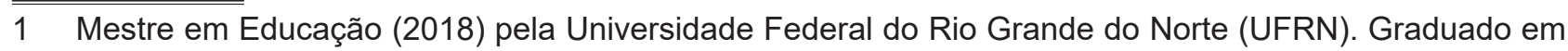
Pedagogia pela Universidade Estadual do Ceará (2015). Especialização em Supervisão Educacional pela Faculdade Venda Nova do Imigrante - FAVENI (2017). Atualmente é Pedagogo na Universidade Federal do Cariri-UFCA. Foi professor substituto na Universidade Estadual do Ceará no Curso de Pedagogia, Campus CECITEC-Tauá.

E-mail: taironelima19@gmail.com

2 Bacharel e Licenciado em Física pela Universidade de São Paulo (1990), Mestre em Ensino de Ciências (Modalidade Física) pela Universidade de São Paulo (1998) e Doutor em Educação pela Universidade de São Paulo (2004). Realizou estágio pós-doutoral na University of Leeds, no Reino Unido (Out/ 2013-Set/2014). Atualmente é professor Associado IV da Universidade Federal do Rio Grande do Norte (UFRN).

E-mail: aferrer34@yahoo.com.br 


\begin{abstract}
The epistemology of Gaston Bachelard criticizes the traditional forms of teaching by understanding education as formation, defending a permanent formation of the subjects. This sense of formation in bachelardian thought runs along the two strands of his work - scientific and poetic - emphasizing the imperative need to experience the real and the unreal for the formation of the subject. It is by a copious process of disillusion, rectification of errors, and removal of obstacles that Bachelard understands the permanent formation of man, which never presents itself a priori objective, but with a past of rectified errors. In this context, the present work aims to evaluate the contributions of Gaston Bachelard's epistemology to the field of education, highlighting the idea of a scientific pedagogy in teaching as a foundation for the development and the formation of a new scientific spirit, opposing to the traditional forms of teaching. To this end, we situate Gaston Bachelard's thought within the French academic-philosophical-cultural context, pointing out the main concepts of his epistemology, and analyzing the contributions of bachelardian thought to the field of education, indicating the need for a new pedagogy in the teaching, defended by the author. This study assumes that the epistemology of Gaston Bachelard has a "pedagogical background" still unexplored, expressed when the author highlights the "pedagogical aspect" that scientific notions encompass. It is a theoretical research on the work of the French philosopher, taking the form of a bibliographical research.
\end{abstract}

Keywords: Gaston Bachelard. Scientific pedagogy. Formation.

Resumen: La epistemología de Gaston Bachelard critica las formas tradicionales de enseñanza al entender la educación como formación y defender la formación permanente de los sujetos. Ese sentido de formación, en el pensamiento bachelerdiano, presenta las dos vertientes de su obra (poética y científica) destacándose la indiscutible necesidad de la vivencia, de lo real y lo irreal, para la formación del individuo. Bachelard entiende la formación permanente del hombre como un proceso de mucha desilusión, rectificación de errores y superación obstáculos, en el que nunca se presenta el objetivo a priori. En este sentido, el presente trabajo tiene como objetivo general investigar las contribuciones de la epistemología de Gaston Bachelard en el campo de la educación, resaltando la idea de una pedagogía científica como fundamento del proceso de enseñanza para la formación y desarrollo de un nuevo espíritu científico, en contra parte a las formas tradicionales de enseñanza. Entre los objetivos específicos está ubicar la línea de pensamiento de Gaston Bachelard en el contexto académico-filosófico-cultural francés e investigar los conceptos principales de la epistemología de Gaston Bachelard analizando sus contribuciones en el campo de la educación, además de esclarecer el porqué de la necesidad de una pedagogía nueva que el autor defiende. Este trabajo está fundamentado en que la epistemología de Gaston Bachelard tiene un "fondo pedagógico" que todavía no fue suficientemente investigado, lo que queda claro cuando el autor expone el "aspecto pedagógico" del conocimiento científico. Es una investigación de tipo teórica sobre la obra del filósofo francés, por lo que puede ser considerada una revisión bibliográfica.

Palabras clave: Gaston Bachelard. Pedagogía Científica. Formación.

\title{
1 INTRODUÇÃO
}

Gaston Bachelard é considerado o filósofo do não. Foi professor de ciências e de filosofia, epistemólogo, poeta, historiador das ciências e eterno aluno. Várias facetas de um mesmo homem que transitou pelas vertentes da ciência e da poesia, vivendo a racionalidade e o devaneio. Nasce em 27 de junho de 1884 no vilarejo de Bar-sur-Aube, região da Champagne no interior da França. Viveu intensamente dois séculos, o perpassar do século XIX para o século XX. Parece ter pertencido a dois mundos, como destaca Dagognet (1965). Nasce na zona rural da França e falece em uma Paris industrializada e cosmopolita no dia 16 de outubro de 1962. A riqueza de sua obra é refletida nos contrastes suscitados por uma vida entrecortada de rupturas e de instantes descontínuos, não obstante decisivos para compor sua singularidade. 
Os estudiosos da obra bachelardiana costumam dividi-la em duas vertentes: uma científica, outra poética, associadas ao pensador "diurno" e "noturno", respectivamente. Nesse sentido, é comum que esses autores escolham apenas uma das vertentes para estudá-la. Michel Vaddé, segundo Bulcão (2009), afirma que podemos entrar no pensamento bachelardiano por vários caminhos; e isso se dá, muitas vezes, por uma das vertentes do seu pensamento. Nesse trabalho, priorizamos o "Bachelard das vinte e quatro horas", isto é, aquele que estuda tanto o conceito como a imagem. Com isso estamos entendendo que, para tentarmos compreendê-lo em sua integralidade, é preciso aceitar o convite do filósofo-poeta de vivermos o dia e a noite em suas "vinte e quatro horas".

Questionado uma vez por Léon Brunschvicg sobre o fato de atribuir tanta importância ao aspecto pedagógico das noções científicas, Bachelard respondeu-lhe dizendo que se considerava mais professor que filósofo. Esse é o Bachelard que fica em nosso espírito ao garimparmos na sua paideia: o Bachelard professor. É que simplesmente nosso autor dizia que "a melhor maneira de avaliar a solidez das ideias era ensinando-as", propondo ainda um paradoxo que, segundo ele, é frequente nos meios universitários: "ensinar é a melhor maneira de aprender" (BACHELARD, 1977, p. 19). Já podemos pensar o porquê de Bachelard defender uma relação docente-discente no racionalismo ensinado, na qual há também uma relação de intersubjetividade no ensino onde o que está em jogo é a racionalidade orientadora do ato de conhecer, presente neste intercâmbio de ideais entre aluno e professor, professor e aluno.

Bachelard desenvolveu suas primeiras teses epistemológicas há mais de oitenta anos e, apesar de parecer muito tempo, seu pensamento continua com a marca da contemporaneidade. A obra de Bachelard tem como fontes o idealismo francês, a Matemática e também a Física de seu tempo (CÉSAR, 2015). Seu diálogo é fruto do seu contexto histórico-cultural. É da análise histórico-crítica da Teoria da Relatividade, das Geometrias Não-Euclidianas e da Física Quântica, principalmente, que surge sua proposta de uma nova filosofia das ciências. Acreditando na prodigiosa fecundidade e da ruptura provocada por estas teorias em relação a conhecimentos anteriores, assinala o surgimento de um "novo espírito científico", marca do racionalismo da ciência contemporânea.

Sua epistemologia tem ganhado cada vez mais espaço nas discussões acadêmicas, principalmente no campo da filosofia da ciência e da epistemologia, onde ela encontra seu habitus. Na área do Ensino de Ciências da Natureza ${ }^{3}$ seu pensamento tem sido bastante

3 De antemão, é importante frisar que Bachelard é um epistemólogo e filósofo da ciência, e suas análises advêm principalmente do interior de ciências como a Física, principalmente, e a Química. As revoluções sofridas no campo da Física, por exemplo, no século XIX, com a Geometria Não-Euclidiana, e início do século XX, com a Teoria da Relatividade e a Mecânica Quântica, provocaram uma ruptura dentro da 
explorado. Entretanto, no campo da educação em geral e, particularmente, da Pedagogia, sua obra tem sido pouco explorada e debatida. Acreditamos que seu pensamento tem importantes contributos ao campo da educação e da Pedagogia.

Ao longo de todos os seus escritos, Bachelard ressalta a importância pedagógica das ideias científicas, fazendo referência a questões relacionadas à escola, ao currículo, ao professor e seus métodos de ensino, ao aluno. Tais preocupações são decorrentes da experiência de Bachelard como professor de ciências e de filosofia no ensino secundário, e como docente no ensino superior. Assim, suas análises pedagógicas advêm da sua preocupação com a construção de uma pedagogia científica no ensino.

São essas questões relacionadas ao campo da educação em geral e, particularmente, da Pedagogia que nos chamam atenção no pensamento bachelardiano. É com o objetivo de avaliar algumas contribuições do pensamento de Bachelard para o campo da educação que este trabalho se orienta. Para tanto, destacamos num primeiro momento os principais conceitos da epistemologia bachelardiana sem, contudo, pretender detalhá-los, uma vez que esbarraríamos na impossibilidade de desenvolvê-los em apenas uma seção. O foco está em destacar apenas aqueles conceitos mais importantes para o nosso objetivo. Num segundo momento são destacadas as relações que esses conceitos mantêm com o campo da educação, procurando sinalizar a ideia de uma educação como formação permanente dos sujeitos, que se dá por um processo constante de afastamento dos obstáculos epistemológicos e eliminação dos erros, procedimento por meio do qual o sujeito se forma ao reformar o próprio pensamento a partir da desilusão com aquilo que se achava sabido e solidificado na memória.

\section{A EPISTEMOLOGIA DE BACHELARD}

A epistemologia de Gaston Bachelard é essencialmente histórica e crítica, e faz da história da ciência seu laboratório epistemológico. A sua filosofia é uma "filosofia do não". Porém, essa filosofia do não "[...] não é uma vontade de negação. Não nega seja o que for, seja quando for, seja como for. É a articulações bem definidas que ela imprime o movimento indutivo que a caracteriza e que determina uma reorganização do saber numa base

ciência que, para Bachelard, constituem o que ele define como o nascer de um novo espírito científico. Então, quando Bachelard fala da ciência ou de ciência, ele está se referindo essencialmente às ciências físico-químicas. Entretanto, como ele se considerava mais professor que filósofo, dará importância capital para os "aspectos pedagógicos das noções científicas", propondo que essa nova ciência necessita de uma pedagogia também nova, isto é, de uma pedagogia científica que, a partir da sua filosofia científica (atenta a essas transformações que aconteceram na ciência), preocupa-se com os fundamentos e desenvolvimentos deste novo espírito científico, o que o levará, por conseguinte, a pontuar questões relacionadas com o ensino, a Pedagogia e a educação, criticando as formas tradicionais de ensino. 
alargada" (BACHELARD, 2009a, p. 117). A filosofia do não representa, antes de tudo, um alargamento e uma reorganização do conhecimento. Daí podemos perceber a novidade aduzida pela epistemologia de Bachelard à filosofia da ciência. Embasada naquilo em que chama de "racionalismo aplicado", é, segundo o autor, a verdadeira filosofia da ciência contemporânea, a qual se constitui uma novidade em si.

Bachelard é, por muitos, considerado um dos autores de maior expressão no campo da filosofia das ciências, inaugurando uma nova concepção sobre a racionalidade - a razão não é da ordem do começo, mas do recomeço, é inventiva e provisória. Bachelard é este pensador que alguns consideram como o "arauto da pós-modernidade" (BARBOSA, 1996).

A sua perspectiva filosófica nasce quando o racionalismo, de um lado, e o empirismo, do outro, filosofias tradicionais que dominavam até então o cenário filosófico, promoviam uma via de mão única na análise da ciência. Bachelard surge com sua proposta epistemológica do "racionalismo aplicado" que, ao contrário, é uma filosofia de "dois polos", ou, como ele próprio sugere, a filosofia que realmente representa os pressupostos da ciência contemporânea.

Assim, Bachelard destaca que, no pensamento científico, a dança de filosofias contrárias - empirismo e racionalismo - abrange as mais diversas filosofias científicas, caracterizando a dialética que move a ciência contemporânea. Segundo o autor, seria mutilar a filosofia da ciência não examinarmos como se situam o positivismo e o formalismo, pois ambos têm funções na Física e na Química (BACHELARD, 1977). Mas, de acordo com ele, o que dá garantias de bom fundamento para a sua posição é que todas as filosofias do conhecimento científico se organizam em torno do "racionalismo aplicado" (BACHELARD, 1977, p. 11), uma vez que, para Bachelard, não existe mais a ideia de realismo nem racionalismo absolutos.

Por isso, a epistemologia de Bachelard envereda no delineamento dos princípios da cultura científica que têm destaque no artefato de suas reflexões e preocupações epistemológicas. É essa necessidade de uma filosofia de dois polos que caracteriza o pensamento científico, já que "[...] O valor de uma lei empírica prova-se fazendo dela a base de um raciocínio. Legitima-se um raciocínio fazendo dele a base de uma experiência. Porque a ciência é a soma de provas e de experiências, soma de regras e de leis, soma de evidências e de factos" (BACHELARD, 2009a, p. 11). Para Bachelard, a aplicação do pensamento científico é essencialmente realizante (BACHELARD, 2000), pois "Desde que se medite a ação científica, verifica-se que o realismo e o racionalismo trocam sem fim seus conselhos [...]" (BACHELARD, 2000, p. 17), fato esse esboçado pelo "racionalismo aplicado". 
No novo espírito científico, a noção de uma existência situada passa a ser uma existência construída, o real torna-se produto da ciência que não mais qualifica um real aparente e imóvel. A noção de objeto apreendido passa para a de objeto a construir. Uma razão imutável passa para uma razão aberta que evolui permanentemente, pois, agora, em vez de uma "lógica dos fenômenos", Bachelard propõe uma "fábrica de fenômenos", na qual a fenomenologia é substituída pela fenomenotécnica (MARTINS, 2004). Dessa forma, segundo a epistemologia bachelardiana, como a ciência contemporânea constrói seu próprio objeto, ela passa a negar a ideia de uma realidade a priori, pois em sua perspectiva somente a imbricação entre o abstrato e o concreto, que o racionalismo aplicado propõe, é que representa verdadeiramente esse novo espírito científico.

A alternância do a priori ao a posteriori é o que caracteriza agora os objetos da ciência que são produtos da mente humana frutos de uma razão realizada. Nesse sentido, quando Bachelard procura analisar as condições psicológicas do progresso da ciência, afirma contundentemente que é em termos de obstáculos que devemos colocar o problema do conhecimento científico, e insiste no caráter de obstáculo que a experiência acarreta. Todavia, Bachelard afirma que não se trata de considerar obstáculos externos, como a complexidade e a fugacidade dos fenômenos, pois "É no âmago do próprio ato de conhecer que aparecem, como uma espécie de imperativo funcional, lentidões e conflitos. É aí que mostraremos causas de estagnação e até de regressão, detectaremos causas de inércia" (BACHELARD, 2016, p. 17), aos quais dá o nome de obstáculos epistemológicos.

Estes obstáculos são inevitáveis e brotam da relação que há entre os sujeitos e os objetos do conhecimento. O perigo encontra-se no ato mesmo de conhecer, pois eles se instalam no inconsciente dos próprios indivíduos. São internos mais que externos. Mais subjetivos do que objetivos.

Podemos afiançar, então, que os obstáculos epistemológicos são contra-pensamentos que se instalam no inconsciente dos sujeitos, e por se basearem nos dados dos sentidos e numa apreensão superficial/acrítica sobre um real aparente, tendem a se manifestarem decisivamente para mascarar o processo da ruptura entre o conhecimento comum e o conhecimento científico (LECOURT, 1980, p. 26), bloqueando e causando a inércia do pensamento. Baseiam-se na experiência primeira, na função generalista, na sedução substancialista, na "intuição da vida", na união do diverso ao idêntico etc. (BACHELARD, 2016). São, portanto, resistências do pensamento ao próprio pensamento, como afirma Dominique Lecourt (1980).

Não pretendemos analisá-los neste trabalho, senão destacar a essência de sua problematização no que concerne ao nosso objetivo. Bachelard aponta para o fato de o conhe- 
cimento científico contemporâneo ser uma ruptura profunda com o conhecimento sensível, pragmático, acrítico, sendo os obstáculos resistências ao modo de pensar os conceitos em suas expressões abstratas e críticas, já que se escondem nas cavernas do espírito que ainda está preso à observação direta dos fenômenos da natureza e à realidade sensível. A experiência primeira ou observação primeira como obstáculo epistemológico, por exemplo, é aquela colocada antes e acima da crítica, não fornecendo, portanto, uma base segura, pois a crítica é elemento constituinte do novo espírito científico. A experiência primeira se apoia numa filosofia fácil, já que "basta descrevê-la para se ficar encantado" (BACHELARD, 2016, p. 25). Antes de tudo, segundo Bachelard, é preciso entendermos que há ruptura, e não continuidade entre a observação e a experimentação. "Não é pois, de admirar que o primeiro conhecimento objetivo seja um primeiro erro" (BACHELARD, 2016, p. 68). É preciso então "[...] aceitar uma verdadeira ruptura entre o conhecimento sensível e o conhecimento científico [...]" (BACHELARD, 2016, p. 294).

Entendemos que os obstáculos albergam uma dupla e importante função: funcionam tanto como o impossibilitador do ato de conhecer o conceito de forma mais crítica, se forem descurados e ocultos no processo de aquisição do conhecimento, como o possibilitador do acesso ao um conhecimento mais elaborado e aproximativo da verdade, se nos tornarmos sujeitos vigilantes e lutarmos para retificar estes obstáculos e instalar a ruptura (sempre permanente) contra esses limites ao conhecimento. Ademais, o que torna interessante o estudo dos obstáculos epistemológicos, segundo Bachelard, é o fato deles poderem também ser estudados na prática da educação, mesmo que isso não seja uma tarefa fácil.

Como Bachelard destaca, é contra esses valores subjetivos representados pelos obstáculos epistemológicos que a psicanálise do conhecimento objetivo deve ser empregada, afastando, por meio de um processo contínuo (que nunca se encerra), tudo que tem origem no inconsciente e que causa prejuízos ao ato de conhecer. De fato, para evoluir o espírito científico precisa superar os obstáculos epistemológicos, retificar os erros que vão se reforçando e destruir o espírito não científico e o que é obstáculo à construção do espírito científico, muito embora essa superação nunca seja definitiva. A análise desse processo se dá, de acordo com Bachelard, na perspectiva do que ele chama de um pluralismo filosófico.

Para Bachelard (2009a), a tarefa da filosofia das ciências expressa em sua "filosofia do não" é a de se tornar uma "polifilosofia", partindo da análise de cada perspectiva filosófica e de suas respectivas influências no desenvolvimento do conhecimento científico. Afirma que a evolução filosófica de um conhecimento científico particular é um movimento que atravessa determinadas perspectivas (escolas) filosóficas, a saber: o realismo, o positivismo, o racionalismo, o racionalismo complexo e o racionalismo dialético, nessa ordem 
(os dois últimos podem ser unidos sob a denominação de "surracionalismo", termo cunhado por Bachelard).

Bachelard propõe, em "A Filosofia do Não", o conceito de perfil epistemológico com base no sistema hierárquico das escolas filosóficas, sugerindo mostrar o que permanece de conhecimento comum no conhecimento científico. Daí, uma "psicologia do espírito científico deveria esboçar aquilo a que chamaremos de perfil epistemológico das diversas conceptualizações". Assim, para Bachelard, "Seria através de um tal perfil mental que poderia medir-se a ação psicológica efetiva das diversas filosofias na obra do conhecimento" (BACHELARD, 2009a, p. 40). ${ }^{4}$

A psicanálise do conhecimento objetivo com o intuito de afastar os obstáculos epistemológicos da construção do pensamento científico se faz mediante o trabalho social na cidadela dos sábios. Bachelard faz uma defesa explícita da forma social da construção do conhecimento científico, pois "[...] Conjuntamente, os sábios unem-se numa das celas da cidade científica, não apenas para compreenderem, mas ainda para se diversificarem, para activarem todas as dialéticas que vão dos problemas precisos às soluções originais [...] (BACHELARD, 1990, p. 10).

A ciência é produto humano. Portanto, o saber científico que se constrói na individualidade não é saber científico, pois o saber encerrado na posse individual precisa ser psicanalisado (BACHELARD, 1977). É necessário, portanto, que os sujeitos da ciência assumam seu lugar na cidadela e produzam dentro da cité, porque é dentro dela que se obedece ao primado de regras pré-estabelecidas a priori e, no fundo, será no domínio do social, segundo Bachelard, que a psicanálise dos obstáculos e a retificação dos erros será possível.

Ademais, tanto o conceito de obstáculo como o de perfil epistemológico têm em comum o fato de reforçar uma das mais essenciais tarefas do sujeito quando se trata de construir o conhecimento científico que, segundo Bachelard, é a função de errar.

Lopes (1996) assegura que, ao recorrermos à história das ciências, logo a veremos marcada por rupturas, uma vez que para chegar no seu estágio atual ela teve que passar por sucessivas retificações dos seus erros. É contra esses erros que dificultam a emergên-

$4 \quad$ Não vamos nos estender na análise do perfil epistemológico, tendo em vista os objetivos e os limites deste trabalho. A ideia básica do perfil epistemológico é a de que, em cada indivíduo, as diversas escolas filosóficas influenciam a pensar determinado conceito sob olhares diferenciados. Além disso, para Bachelard (2009a), o que torna interessante o estudo do perfil epistemológico é que ele reflete o desenvolvimento de um conceito determinado e válido para um espírito particular. Para sujeitos diferentes, perfis diferentes. Além disso, é importante destacar que, assim como a superação dos obstáculos não se dá de maneira definitiva, também a evolução filosófica de cada perfil, possibilitando a construção de novas "zonas", não significa o desaparecimento de concepções precedentes (MARTINS, 2004). 
cia de valores e conceitos mais racionais que devemos envidar esforços para retificá-los. Porém, para Bachelard, o erro assume uma conotação positiva. Não é mais encarado como um desvio de percurso que deve ser evitado, nem uma espécie de limitação do pensamento. É antes a consciência do erro que garante o percurso da objetivação. A dialética do erro exerce sistematicamente uma dupla função: negativo enquanto estágio necessário para a superação de um obstáculo; e positivo quando retificado e psicanalisado, tornando-se a "mola propulsora" para a aquisição de novos saberes mais aproximativos da verdade (MARTINS, 2004). Como toda cultura científica deve começar por uma verdadeira "catarse intelectual e afetiva", o novo espírito científico surgiria, então, como um conjunto de erros retificados, proporcionados pela psicanálise do conhecimento objetivo (MARTINS, 2004).

Pensamos que para tentar compreender o pensamento bachelardiano em seu dinamismo e movimento é necessário aceitar o seu convite de viver as "vinte e quatro horas", isto é, viver o mundo dos conceitos, mas também o mundo da imaginação. Portanto, o pensamento de Bachelard se desdobra em duas vertentes que se alternam na apresentação ora dos conflitos, ora das alianças; ora da unidade, ora da oposição em seu pensamento.

É bem verdade que Bachelard acentuou que "os eixos da ciência e da poesia são inversos", "são dois contrários bem feitos". Seu pensamento é uma espécie de "movimento", e talvez resida aí, numa simples palavra, uma luz que clareia nosso caminho em sua paideia, uma vez que a ciência, para Bachelard, é descontínua e está constantemente a progredir e a retificar-se. As imagens poéticas, o devaneio, os sonhos, nos dão o impulso para um voo ascensional em busca do infinito e, talvez, de nossa verdadeira essência, nos colocando em constante movimento a partir de um onirismo ativo e dinâmico. A imaginação, em Bachelard, é tida como uma forma de se buscar o infinito e de criar novas imagens, de ir além do visível, colocando o hábito como a exata antítese da imaginação criadora. Bachelard nos convida a viver uma dialética de compreender a realidade como um poder de sonho, e o sonho, uma realidade.

No entanto, não devemos concluir que Bachelard aborda a ciência como poeta ou investiga os seus sonhos e devaneios através de teoremas (JAPIASSÚ, 1976a). Aliás, "Os poemas ocultam os teoremas", como dizia o próprio autor em "A Psicanálise do fogo". Todavia, isso não sugere que ciência e poesia não possam conjecturar uma unidade de inspiração, o que nos parece ter ocorrido em Bachelard: ciência e poesia inspiraram nosso filósofo-poeta e fizeram-no pensar o mundo das ideias através de uma imaginação que tem a capacidade de criar este mundo, em vez de apenas reproduzi-lo.

Em O ar e os sonhos, Bachelard adverte que as pesquisas sobre a imaginação são dificultadas pela falsa luz da etimologia. Para ele, a noção de imaginação que temos habi- 
tualmente é sempre contrária ao seu real sentido. Ele diz que "Pretende-se sempre que a imaginação seja a faculdade de formar imagens. Ora, ela é antes a faculdade de deformar as imagens fornecidas pela percepção, é sobretudo a faculdade de libertar-nos das imagens primeiras, de mudar as imagens [...]" (BACHELARD, 2001a, p. 1). A imaginação é, portanto, a faculdade de ir além da realidade, de formar imagens que ultrapassam a condição sensível do real.

Para Bachelard, para que ocorra uma ação imaginante, tem que haver a mudança de imagens e a união inesperada de imagens, ou seja, tem que existir a deformação de imagens para a formação de novas imagens. Deste modo, não há imaginação "[...] Se uma imagem presente não faz pensar numa imagem ausente, se uma imagem ocasional não determina uma prodigalidade de imagens aberrantes, uma explosão de imagens [...]". Assim, "[...] O vocábulo fundamental que corresponde à imaginação não é imagem, mas imaginário. O valor de uma imagem mede-se pela extensão de sua auréola imaginária [...]" (BACHELARD, 2001a, p. 1).

Podemos entender então que "[...] razão e imaginação são, na obra do autor, caminhos de 'sobre-humanidade', o que significa dizer que tais atividades se impõem como verdadeiros atos prometeicos que conduzem o homem numa aventura em direção ao novo, ao imprevisto, ao surreal [...]" (BULCÃO, 2010, p. 177). Foi pelo caminho da razão e da imaginação, considerados verdadeiros voos ascensionais (BULCÃO, 2010), que Bachelard alcançou um reino novo, surreal e imagético, contraído apenas através do ato de criação, como ressalta Bulcão.

Bachelard coloca-se no seio de uma "[...] filosofia da imaginação para a qual a imaginação é o próprio ser, o ser produtor de suas imagens e de seus pensamentos. A imaginação dinâmica ganha então a dianteira sobre a imaginação material [...]" (BACHELARD, 2001a, p. 109). E "[...] Para esclarecer filosoficamente o problema da imagem poética, é preciso chegar a uma fenomenologia da imaginação [...]". Logo, sua fenomenologia da imaginação consiste em "[...] um estudo do fenômeno da imagem poética no momento em que ela emerge na consciência como um produto direto do coração, da alma, do ser do homem tomado na sua atualidade" (BACHELARD, 1993, p. 2). É necessário que o filósofo esqueça todo o seu saber advindo da ciência e do racionalismo se quiser aventurar-se em tal estudo.

Para Wunenburger (2003), na fenomenologia da imaginação, Bachelard liberta-se de sua análise inicial voltada e presa ainda ao controle científico, para realizar o que ele chama de "imaginação sem imagens", ou como compreende Wunenburger, um tipo de "desimaginação". Seu pressuposto é o estudo da imagem não como representação, mas como trans- 
formação e deformação dessas imagens, passando por um processo de "desaparecimento da imagem", numa expressão de Wunenburger (2003).

É na obra O Ar e os sonhos (1942) que Bachelard distingue os dois tipos de imaginação para a compreensão do fenômeno poético, em que esses correspondem aos quatro elementos da matéria - água, fogo, ar e terra - de onde também se constituem as imagens poéticas. O primeiro conceito seria o de imaginação formal, que dá origem à causa formal. O segundo seria o de imaginação material, que dá origem à causa material. A criação poética necessita tanto de um como do outro para a criação de imagens. A imaginação formal está vinculada ao racionalismo e à função do real, e o contato do homem com o mundo incide basicamente da observação e da reprodução. Já a imaginação material tem a necessidade de "penetração", ou seja, busca ir além das seduções da imaginação das formas, ela procura atingir até o íntimo da matéria, ela vai pensar, viver e sonhar na matéria, isto é, "materializar o imaginário" (BACHELARD, 2001a, p. 9-10). Assim, temos a possibilidade de uma imaginação criadora que, através do contato com a matéria, provoca no psiquismo uma dinâmica nova, impulsionando a produção de imagens inteiramente novas. Ela busca superar e transformar a matéria, e não apenas reproduzi-la.

Com Bachelard, segundo Wunenburger (2010, p. 41), "[...] o poder de conhecimento ou de sonho de nossas representações provém menos das características internas das ideias ou imagens que de uma energia intelectual do sujeito, de um tônus psíquico [...]". Para Wunenburger, tanto a nossa produção imaginativa como a nossa invenção conceitual em ciência colocam em jogo forças cujo poder e propensão são fatores primordiais do trabalho intelectual de cada sujeito. Isto requer do indivíduo uma força psíquica mais forte, uma energia intelectual mais vibrante (WUNENBURGER, 2010). Talvez seguindo a trilha da fenomenologia e da psicanálise, a contribuição de Bachelard à filosofia do conhecimento consiste em "substituir esta abordagem estática e formal por uma concepção 'dinamogênica' das atividades intelectuais" (WUNENBURGER, 2010, p. 41). Ademais, poderíamos dizer que, em Bachelard, a imaginação criadora tem seu lugar tanto na poética como na ciência, pois ambas, ao possibilitarem a superação e a renovação do mundo, acabam por se tornar ontogênicas - mas não idênticas - como Bachelard ressaltou.

Contudo, imaginar é "ausentar-se, é lançar-se a uma vida nova" (BACHELARD, 2001a, p. 3), a uma vida poética, de imagens, de liberdade e de essência vital para o homem. A imaginação criadora dinamiza o ser e tem o poder de libertar o seu espírito para lançá-lo em um voo ascensional. Bachelard diz haver uma ponte entre a terra e o céu, entre o finito e o infinito. A imaginação é provocativa, faz o ser viver o dia e a noite em suas vinte e quatro horas. Viver em animus e em anima. Bachelard escolheu viver dessa forma. 


\section{BACHELARD E A EDUCAÇÃO}

Compreendemos a perspectiva da educação no pensamento bachelardiano como formação do sujeito a partir das duas vertentes do seu pensamento, isto é, o sujeito se forma concomitantemente a partir da sua vivência no mundo dos conceitos e das imagens. Por sua vez, a aprendizagem se dá numa relação de intersubjetividade, na qual o racionalismo docente-ensinado prefere perguntas às respostas, proporcionando um ensino mediante a complicação da lição, dos métodos, contrapondo-se meramente à apresentação dos resultados da ciência. Deste modo, entendemos que "o projeto epistemológico de Bachelard não se encontra desvinculado de um 'projeto pedagógico'” (MARTINS, 2004, p. 30), mas que sua pedagogia científica ${ }^{5}$ está intimamente relacionada com a sua epistemologia a partir dos conceitos que formam a seara do seu pensamento.

Mas o que seria essa pedagogia científica? A Pedagogia que subjaz da epistemologia de Gaston Bachelard extrapola os domínios tradicionais da formação humana ${ }^{6}$ e constituise a partir de uma filosofia científica que concentra algumas de suas ideias para o campo da educação, uma vez que, ao longo de suas obras e dos seus cursos, segundo Pessanha (1978), Bachelard defendia e insistia na seguinte tese: "a filosofia científica deve ser essencialmente uma pedagogia científica"' (BACHELARD, 2008b, p. 75, grifos nossos). Segundo Pessanha, a preocupação de Bachelard era com os fundamentos para o desenvolvimento de um novo espírito científico, que o levaram, a partir da sua pedagogia científica, a propor: "para uma ciência nova, uma pedagogia nova" (BACHELARD, 2008b,

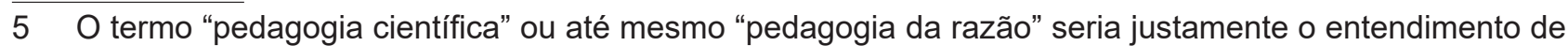
Bachelard sobre ser essa ciência nova uma pedagogia permanente, isto é, ela está em constante aprendizagem e transformação através do trabalho social dos sábios na cidade científica, que por meio de uma constante busca de retificação dos erros e da superação dos obstáculos epistemológicos vai formando e reformando o espírito científico. Assim sendo, Bachelard entende que essa pedagogia que caracteriza a ciência contemporânea, isto é, uma ciência em mutação e reforma constante, deverá ser a pedagogia científica que se propõe a ensinar essa ciência nas escolas, uma ciência que não tem o fito de produzir verdades imutáveis, senão que busca se aproximar delas; uma ciência que retifica erros e supera obstáculos; uma ciência em pedagogia permanente. Por isso que seu projeto epistemológico alberga intimamente um projeto pedagógico. Não se trata, portanto, de "cientificizar" a pedagogia, como pode parecer à primeira vista.

6 Isso quer dizer que entendemos como domínio tradicional da formação humana a educação que acontece de maneira formal e institucionalizada na escola, pois a essa é creditada como a instituição (formal de ensino) encarregada de desenvolver e "disseminar" a cultura da humanidade. Daí, como Bachelard discute o sentido de uma formação permanente, a educação para ele constitui-se num processo de formação como reforma dos sujeitos, extrapolando esse sentido tradicional de formação centrada na escola que cultivamos em nossa sociedade.

7 A pedagogia científica que Bachelard discute não tem correspondência direta com as discussões sobre a Pedagogia como ciência. Sendo assim, não é objetivo de Bachelard discutir um objeto, método, critérios etc., próprios de determinada área que se pretenda científica. 
p. 75-76, grifos nossos). Assim, podemos dizer que esta pedagogia científica se traduz na visão bachelardiana de que o racionalismo da ciência contemporânea, que está em permanente estado de mudança, também deve estar presente no ensino a partir de um racionalismo docente-ensinado, no qual a formação do espírito científico, começando pela educação que inicialmente se dá na escola, constitui-se num processo incessante de formação do homem e como movimento constante de deformação e reforma do sujeito a partir de uma pedagogia nova para esta ciência também nova.

A vertente epistemológica do pensamento de Bachelard parte da ideia de que a construção do conhecimento é algo próprio do sujeito, isto é, acontece por meio de sua ação e pelo seu esforço de pensar e abstrair-se, o que também acontece no que se refere à vivência poética do sujeito, contribuindo para a sua formação. A partir disso, podemos entender que o esforço de Bachelard foi entender a importância da educação para a formação dos sujeitos num sentido pleno do termo, ou seja, dentro de uma perspectiva educativa que não visa apenas formar o homem para o trabalho, mas que o conduza a viver em harmonia com o mundo e consigo mesmo, o que se reflete nas duas vertentes do autor que são ao mesmo tempo antagônicas e complementares; no seu esforço de vivenciar o mundo dos conceitos e o mundo das imagens, resgatando o sentido de uma educação que confere valor ao pensamento e à vivência do irreal (CRUZ, 2005). Portanto, entendemos, seguindo Japiassú, que "a pedagogia científica de Bachelard mostra claramente que os espíritos, longe de se confundirem, se implicam, se opõem e exercem uma vigilância recíproca. A ciência exige a permuta dos 'papéis' (mestre-aluno)" (JAPIASSÚ, 1976a, p. 78).

Os novos pressupostos da ciência e do racionalismo que implicam à escola são tratados na epistemologia de Bachelard (2000) ao afirmar que a acumulação do conhecimento não é o que faz a sua estrutura, mas as retificações e as extensões é que são as verdadeiras molas do pensamento científico. E como "o conhecimento científico será sempre a reforma de uma ilusão", pois "é no momento que um conceito muda de sentido que ele tem mais sentido" (BACHELARD, 2000, p. 51, grifos do autor), Bachelard se coloca do ponto de vista pedagógico, pois destaca o valor psicológico do ensino ao defendê-lo na perspectiva da complicação, ou seja, fazer o aluno compreender, por exemplo, que determinado conceito pode ter passado por várias e sucessivas retificações e mudado de sentido várias vezes até chegar ao seu estágio atual.

O racionalismo defendido por Bachelard é adepto da construção do conhecimento a partir dessas permanentes retificações, e isso pode impactar a forma como compreendemos a educação dos sujeitos, uma vez que "[...] Verdadeiro sobre fundo de erro, tal é a forma do pensamento científico. $O$ ato de retificação desfaz as singularidades ligadas ao erro 
[...]" (BACHELARD, 1977, p. 60), implicando ainda uma tese singular: "[...] substituir a historicidade da cultura pela reorganização da cultura [...]" (BACHELARD, 1977, p. 60), isto é, o conhecimento como construção permanente do homem, o que implicará valor especial à formação do homem que não mais buscará acumulá-lo, mas reorganizá-lo em bases cada vez mais alargadas. Portanto, "[...] Bachelard entende, desse modo, que os ensinamentos da racionalidade científica, vista desde a sua operatividade efetiva e não na morbidez dos resultados fixos e fixistas, encetam um plano pedagógico inelutável" (SILVA, 2003, p. 104).

A pedagogia científica de Bachelard se nutre da sua epistemologia histórica e dialética, dando sentido ao seu projeto pedagógico. Concordamos com Silva (2003) que Bachelard, a partir de sua experiência como professor, conseguiu articular como ninguém três campos do conhecimento: o filosófico, o científico e o pedagógico (e acrescentaríamos o poético), os quais contribuíram para a formação da estrutura mestra do seu projeto cultural (SILVA, 2003, p. 103), o que pode ser percebido na sua tese da filosofia científica ser essencialmente uma pedagogia científica, que se refletiu em suas críticas ao ensino de sua época, particularmente sobre um ensino de ciências tradicional e a prática pedagógica dogmática dos professores. Essa pedagogia científica nutre-se da sua epistemologia, da sua filosofia do não e do seu racionalismo aplicado. Visa propor os rudimentos de uma nova Pedagogia na escola que assuma os compromissos ensejados por sua filosofia científica no campo epistemológico.

Barbosa e Bulcão (2011) assinalam que o processo objetivo de gênese do conceito e da imagem refere-se sempre ao subjetivo. Por isso a ideia de formação. Por outro lado, não podemos "pensar a educação como a aventura de um sujeito cuja razão ou imaginação não teriam objeto e permaneceriam vagando em um vazio didático [...]" (BARBOSAE BULCÃO, 2011, p. 51-52). Temos que pensar o sujeito no seu esforço imaginativo e racional a partir da construção de um objeto e de como esse processo implica na mudança tanto do sujeito, no processo de construção dos conceitos, como também do objeto que pelo sujeito é construído. Daí que, para Bachelard, a formação integral do sujeito alcança sentido quando ela é feita tanto a partir da vertente científica como poética, pois ambas fazem parte da vida do homem que alternadamente pensa e sonha. Portanto, as contribuições pedagógicas de Bachelard para a formação do sujeito albergam uma vertente diurna (vivência do real) e outra vertente noturna (vivência do irreal).

Para Bachelard, a noção de educação como um processo constante de formação do sujeito se dá através de retificação dos erros, desilusão com aquilo que se achava sabido e solidificado e, portanto, da ruptura com o meu próprio eu intelectivo. Assim, o sujeito ganha um novo contorno: a formação do sujeito só acontece quando há reforma 
e desconstrução do sujeito (BARBOSA E BULCÃO, 2011), ou seja, quando ele retifica e rompe com um saber anterior, quando renuncia a viver na saudável precaução das ideias já apreendidas e acumuladas no seu doce ego. Ora, para nosso autor, para que possamos construir um novo saber, antes é preciso romper com o antigo, isto é, o conhecimento novo sempre se dá contra um conhecimento anterior. Esse dinamismo do espírito que se refaz constantemente implica a formação do sujeito como a reforma do espírito e a deformação do pensamento como a melhor maneira da formação de novas ideias. "O conhecimento é, assim, um trabalho ativo, um trabalho ativo no que diz respeito ao objeto, como também no que diz respeito ao sujeito" (BARBOSA E BULCÃO, 2011, p. 55).

O sujeito, diante do objeto, trabalha em função de eliminar suas impressões primeiras advindas desse primeiro contato e que o impedem de atingir o conhecimento objetivo. Há nesse processo um trabalho rumo ao processo de objetivação do conhecimento pelo sujeito que, se colocando em polêmica interior, muitas vezes pelo exercício de pensar a si próprio, vai eliminando pouco a pouco suas impressões subjetivas e caminha em direção ao conhecimento objetivo e racional, fruto desse trabalho ativo sobre a aquisição do seu próprio conhecimento.

Mas a construção do conhecimento não se evidencia pela reprodução de certezas e muito menos pela contemplação de ideias. Esse processo deve visar sempre o saber novo, provisório. Para Bachelard, por mais intuitiva que seja a origem de uma ideia, nenhuma contemplação pode nos oferecer essa ideia de imediato (BACHELARD, 2008b). Além disso, não temos como saber se nosso ser está totalmente concentrado numa simples contemplação. Nesse processo de objetivação, dá-se a relação entre a produção dos conceitos e o sujeito que se transforma ao longo desse processo de produção.

Concordamos com Barbosa e Bulcão (2011, p. 52) que Bachelard usa o termo "formação" num sentido amplo, pois ao mesmo tempo ocorre trabalho do objeto e trabalho do sujeito. No limiar há a construção dos conceitos e de ideias, isto é, trabalho sobre o mundo objetivo; em seguida ocorre a permuta de um desenlace para um trabalho subjetivo no sujeito que se transforma ao construir o objeto. Assim, "[...] é preciso refletir num ritmo oscilatório de objetivação e subjetivação. É preciso pensar e ver a si próprio pensando [...]" (BACHELARD, 2008b, p. 78). Logo, é necessário que a objetividade seja sempre reconquistada, acompanhada de uma consciência de objetivação. Portanto, o conhecimento é um processo constante de conquista e perda da objetividade objetivada, para que se possam ter claros os planos diversos de suas correlações (BACHELARD, 2008b).

Deste modo, não há como nos apreender como um sujeito puro e distinto. Aqui, reside uma crítica feita por Bachelard ao cogito cartesiano que recai no fato de um conhecimento 
poder constituir-se objetivo a priori. Para ele, "Nenhuma ideia isolada traz em si a marca de sua objetividade. A toda ideia é preciso juntar uma história psicológica, um processo de objetivação para indicar como essa ideia chegou à objetividade [...]" (BACHELARD, 2008b, p. 77). Por isso, no processo de objetivação há um trabalho constante do sujeito que constrói conceitos por meio da retificação desses erros profundos e diversos, afastando as primeiras impressões que tendem a se manifestar sobre o objeto se constituindo em obstáculos que se interpõem no ato mesmo de pensar os conceitos. A objetivação é um processo dinâmico e constante e sempre aproximado, pautado numa relação dialética de apropriação e perdas constantes. É a partir dessas aproximações sucessivas que se legitimam os progressos da objetivação e da subjetivação. Para ele, só há conhecimento quando há retificação do saber, o que implica constantemente na reforma das bases do conhecimento. Desse modo, é difícil nos colocarmos como sujeitos puros e distintos, já que "O pensamento começa por um diálogo impreciso em que sujeito e objeto se comunicam mal, porque ambos são diversidades desencontradas" (BACHELARD, 2008b, p. 77).

Entendendo que o "espírito científico deve formar-se enquanto se reforma" (BACHELARD, 2016, p. 29), a função da escola seria colocar no centro do processo dessa formação a ruptura e a retificação desses erros mais íntimos e subjetivos. Como os alunos já chegam à escola com conhecimentos já sedimentados pela vida diária, a tarefa do professor seria levar a formação dos sujeitos a um outro patamar, ou seja, aos ditames do pensamento racional, que somente através do pensamento ascético, abstrato, levaria à formação do espírito científico. A formação conduz então para uma necessidade de construir a todo instante novas bases para o conhecimento, pois ela é um processo permanente.

Bachelard (2016) afirma que ninguém pode arrogar-se o espírito científico, enquanto não estiver totalmente seguro de "reconstruir todo o próprio saber" e consciente de que "só os eixos racionais permitem essa construção" (BACHELARD, 2016, p. 10), através do exercício de pensar o novo. O sujeito deve estar consciente de que a "[...] paciência da erudição nada tem a ver com a paciência científica", e cultivar um desinteresse pela busca utópica da completude do saber, "[...] Já que todo saber científico deve ser reconstruído a cada momento [...]" (BACHELARD, 2016, p. 10), devendo ser natural o desapego por esse interesse. Não existe construção de conhecimento sem a retificação do anterior e a reforma de uma ilusão.

Para o autor, nada mais saudável e prazeroso do que superar o peso da dificuldade de um saber difícil. Porém, se para chegar à conclusão é preciso errar, surge, segundo Bachelard, a função mais essencial da atividade do sujeito, ou seja, a função de errar. Diz ele que "[...] Quanto mais complexo for seu erro, mais rica será sua experiência. A experiência 
é precisamente a lembrança dos erros retificados. O ser puro é o ser que saiu do engano" (BACHELARD, 2008b, p. 79). Assim, Bachelard diz que "só somos originais por nossos erros", e é pelo "relato de minhas renúncias que assumo para o outro uma aparência objetiva" (BACHELARD, 2008b, p. 85).

Então, não sou o que aparento ser, só alcançarei um retrato objetivo pelo reflexo de minhas renúncias subjetivas. Bachelard propõe um paradoxo pedagógico que está na base da cultura: "[...] a objetividade de uma ideia será tão mais clara, tão mais distinta quanto mais surgir de um fundo de erros profundos e diversos. É em função do número e da importância dos erros anteriores que se mede o critério de distinção proposto como diferente do critério de clareza" (BACHELARD, 2008b, p. 78). Precisamente, o sujeito desenganado é aquele que tem a consciência das suas faltas e, consequentemente, da retificação dos seus erros. E é a partir dessa função de errar que o sujeito ascende a uma nova constituição de si. Desta vez, desiludido pela retificação dos erros. Ao promover o exercício de retificação e reforma do pensamento, poderei definir o limiar desse processo da seguinte maneira: "sou o limite de minhas ilusões perdidas" (BACHELARD, 2008b, p. 86). Serei eu agora mais puro e distinto, porque não acasalei com a inércia espiritual de um passado cheio de (in) certezas.

Para Bachelard, uma educação permanente deve estar na base de uma escola permanente e de um projeto educativo permanente. A partir disso podemos dizer, seguindo Barbosa e Bulcão (2011), que Bachelard prefere o termo formação à educação, justamente pelo fato desse último carregar consigo toda uma bagagem cultural tradicional que atrela a ação de construção do conhecimento a um processo contínuo e ininterrupto no qual o sujeito vai somando conhecimentos através do ato da memorização e da repetição de ideias, quando, na verdade, ele se dá através da incisiva luta em afastar os obstáculos epistemológicos e as visões a priori do espírito. O conhecimento para o sujeito será sempre mais uma renúncia do que uma conquista, pois a aquisição do saber só se evidencia a posteriori, após a abdicação do que parecia ser seguro e retido no porto seguro da memória.

Se a construção do conhecimento se dá mediante a ação do sujeito no seu esforço de objetivação e subjetivação, que em um trabalho permanente de afastamento dos erros vai se desiludindo, esta ação do sujeito implica igualmente em sua formação, pois ela é requerida também em sua vivência poética, a qual se exige engajamento e espírito criador. Assim, a educação, nesta perspectiva, deve abandonar o espírito conservativo (instrucional e funcional apenas), em favor da aquisição de um espírito criador (CRUZ, 2005). A educação, nesse sentido de um espírito aberto e dinâmico, deve "[...] considerar a beleza do ato criador presente tanto na atividade do pensamento quanto na atividade poética. Deve chegar a uma estética do humano" (CRUZ, 2005, p. 41). 
Concordamos com Cruz (2005) quando afirma que há na compreensão de Bachelard a concepção de que a objetivação da ciência moderna, assim como a vivência poética, se dá mediante a ação do sujeito, na medida em que "o poema é lido e o teorema se produz, forma-se concomitantemente o sujeito" (CRUZ, 2005, p. 1). Logo, a educação não pode ser entendida apenas na sua forma utilitária, isto é, de uma forma funcional que prepara o homem para uma vida produtiva em sociedade. A perspectiva de Bachelard, quando fala do conhecimento e da vivência poética, segundo a autora, "[...] refere-se a algo que acontece do interior de um psiquismo, conferindo ao espírito uma dinamicidade [...]" (CRUZ, 2005, p. 2, grifo da autora), podendo contribuir para pensarmos numa educação que fuja deste sentido que não consegue preparar o homem para viver o real e o irreal, conforme indica a perspectiva bachelardiana de formação do sujeito.

Por isso, entendemos que o sentido de formação na obra deste autor pode nos ajudar a pensar a educação como formação do sujeito tanto pela atividade cientíica como pela vivência poética; a vivência ao mesmo tempo do real e do irreal. "[...] É que Bachelard realmente leva a sério a necessidade do sujeito se alternar entre o real e o irreal, o dia e a noite [...]" (CRUZ, 2005, p. 3) para conseguir lançar-se a uma vida nova, uma vida de devaneios, de ascensão vertical.

Então, a educação pode ser entendida como a forma de possibilitar que o espírito do sujeito possa evoluir em busca de sua compreensão do mundo e, ao mesmo tempo, desfixar-se dele para formar-se enquanto refaz seu pensamento pelo exercício de pensar 0 conceito e a imagem. O trabalho educativo em sala de aula, o qual Bachelard destaca como sendo uma relação docente-discente seria, portanto, o possibilitador da formação/deformação do sujeito, tanto na perspectiva do professor como do aluno, pois os papeis podem se inverter na dinâmica desta Pedagogia da formação intersubjetiva.

Tanto na vertente científica como poética o espírito precisa estar aberto ao novo e ao abrupto, a colocar-se num movimento dialético de reforma de si, e do conhecimento que se vai construindo. E mesmo compreendendo que a imaginação que Bachelard propõe seja fruto de um outro estatuto epistemológico, como destaca Cruz (2005), posto que está no solo propriamente da subjetividade, ela desemboca numa mesma concepção acerca do conhecer, isto é, em ambos os lados exige-se ação, criatividade, mudança, reforma, invenção de mundos, como diz a autora. Exige-se movimento em busca de pensar sempre de uma outra forma. E se o ato de conhecer é ação, invenção e mudança, a educação não pode se resumir a expor verdades e conteúdos, mas possibilitar o debate e o exercício de pensar estes conteúdos como possibilidade de sua formação para um refletir e agir no mundo. 
No desenvolvimento de suas obras do lado poético, Bachelard demonstrou uma preocupação especial com a formação plena do ser que não deve resguardar-se o direito de sonhar, mas buscar uma ascensão vertical, viver o "tempo vertical", isto é, o tempo da poesia. Para o autor, "[...] enquanto o tempo da prosódia é horizontal, o tempo da poesia é vertical [...]" (BACHELARD, 2007, p. 100). Este é um tempo que não segue uma medida, mas foge do tempo comum, o qual incide também sobre a formação do sujeito pela vertente poética.

O conceito de tempo tem importância capital para entendermos o sentido de formação através da vivência também do irreal, pois sua concepção de tempo descontínuo, fundamentada em Gaston Roupnel e em contraposição à ideia de tempo como duração, de Henri Bergson, é fundamental para compreendermos o sentido de uma formação permanente na obra do autor. O vivenciar de obras poéticas não pode ser considerado puro deleite, mas, assim como no campo dos conceitos, onde se exige invenção e construção, no campo da poética também tem que existir desejo, ação, criação e construção de imagens que captam o real, mas que também possam ultrapassá-lo. Assim, a ideia de tempo como instante, desenvolvida por Bachelard, desemboca no sentido de que, para ele, a construção das imagens poéticas emerge na consciência do sujeito num instante que é solidão.

Enquanto Bergson defendia a ideia de tempo como duração, qualitativo e associado ao tempo vivido, para Bachelard, o tempo só tem uma realidade que é a do instante, pois "o tempo é uma realidade encerrada no instante e suspensa entre dois nadas". Segundo Bachelard, "o tempo poderá sem dúvida renascer, mas primeiro terá de morrer. Não poderá transportar seu ser de um instante para outro, a fim de fazer dele uma duração. O instante é já solidão [...]" (BACHELARD, 2007, p. 17-18). Bachelard refuta a ideia de continuidade temporal que, para ele, não passa de uma construção da nossa inteligência que une linearmente os instantes, dando-nos a impressão que o tempo tem uma continuidade e duração (BARBOSA E BULCÃO, 2011), mas acredita que o tempo é pontuado por instantes descontínuos, e o que dá a ele a aparência de duração é a repetição de ritmos através de uma reconstrução psicológica.

Foi por um esforço consciente que Bachelard expôs a dinâmica da ciência contemporânea de criação de objetos, de pensar os fenômenos, como foi também o de entender o estudo da imagem pela imagem, e não apenas como representação de algo. Em ambos os casos, Bachelard nos convida à difícil tarefa de trabalhar os conceitos e as imagens (CRUZ, 2005). Tanto em um como no outro exige-se do pensamento um engajamento necessário para a invenção do mundo dos conceitos e das imagens, porque em ambos se exige do 
espírito construção: construção do mundo dos conceitos e construção do mundo das imagens. Nos dois é preciso refletir, pensar e agir.

Portanto, a formação plena do ser, em Bachelard, dá-se pelas duas vias de seu pensamento. Porém, não há conciliação entre o onirismo e o racionalismo. Não há síntese possível. Trata-se de duas linhas divergentes, mas que fazem parte da vida e evolução espiritual de cada sujeito (CRUZ, 2005). A "antropologia completa” de Bachelard se dá, segundo a autora, por uma completude que não pode ser entendida como uma generalidade homogênea, mas composta pelos "dois contrários bem feitos". Ensinar o homem a pensar e construir o mundo dos conceitos e a viver a plenitude da vivência das imagens poéticas seria um aspecto formativo interessante que a educação poderia proporcionar, pois daria, pelo complemento das duas linhas divergentes, um plano de ascensão vertical mais completo do sujeito.

Daí podemos pensar a formação do sujeito no instante em que ele vivencia o real e o irreal, pois assim como a construção do conhecimento se dá por retificações, sendo necessário um trabalho permanente em busca de ultrapassar os obstáculos epistemológicos, e de romper com um saber anterior, a atividade poética também tem como característica ser uma "novidade em si", como ressalta Bachelard, colocando o sujeito sempre em movimento na busca de desfixar-se do tempo horizontal e viver o tempo vertical, pois assim como o tempo da ciência, o da poética eleva o sujeito à verticalidade. A formação do sujeito entendida nesse sentido é um ritmo oscilatório entre a vivência racional do dia e a vivência e libertação da imaginação à noite.

3.1 A aprendizagem na perspectiva bachelardiana: a relação de intersubjetividade entre professor-aluno

Aprender na epistemologia bachelardiana é um ato de renúncias no qual vai se dando a formação do sujeito. Aprendemos sempre contra um conhecimento anterior, superando os obstáculos epistemológicos e retificando os erros. Aprender é um ato constante de desilusão com aquilo que julgávamos saber. Será sempre mais uma renúncia do que uma conquista.

Na epistemologia bachelardiana há uma operação com um duplo aspecto pedagógico: para demonstrar a coerência de uma ideia aprendida é preciso colocá-la em confronto com outro espírito, isto é, mediante o processo de ensino desta ideia, no qual só ensinará quem efetivamente aprendeu. Bachelard defende a inversão constante das dialéticas: o professor deve se tornar um eterno estudante e o aluno professor e, dessa forma, veremos 
se constatar, segundo Lopes (1993), o empreendimento da operação dialógica na análise bachelardiana: "[...] para o aprendiz se capacitar a ensinar é preciso a reconstrução do conceito a ser transmitido. Isso só será possível com a organização coerente do pensamento". Concordamos com Lopes que "Não há ensino onde não houve aprendizagem, não existe a passagem do conceito por mera repetição do dito, como informações percorrendo uma correia de transmissão" (LOPES, 1993, p. 325).

A atividade de ensinar é, para Bachelard, a capacidade discursiva que o ato de aprender representa no plano dialógico do ensino no racionalismo docente. A atividade de ensinar exige o polo do aprender, uma vez que o professor só terá ressonância da aprendizagem do aluno quando este for capaz de ensinar o que aprendeu.

Temos que discordar de Costa (2015) quando afirma que Bachelard não inovou em princípios e métodos pedagógicos, uma vez que a sua preocupação com a atividade cognitiva do sujeito frente ao conhecimento científico, não devendo descurar dos obstáculos epistemológicos, marca um princípio pedagógico de que o conhecimento não nasce do nada, mas está propenso aos erros e aos obstáculos, pois Bachelard defende que os obstáculos epistemológicos estão presentes no próprio ato de conhecer. Também acreditamos que a importância dada à referida relação intersubjetiva entre professor e aluno, em que ambos são sujeitos do processo de ensinar e aprender, também se torna um princípio pedagógico elementar não só em Bachelard, mas em qualquer Pedagogia que considere os dois polos do ensino.

Com efeito, para Bachelard (1977), o racionalismo docente exige a aplicação de um espírito a outro, e é no ato de ensinar, permeado por discussões, que surge a oportunidade de avaliar e discutir melhor o valor e a solidez das nossas ideias, desobstruindo, no processo de ensino-aprendizagem, o peso e o valor das nossas primeiras convicções. Todavia, segundo o autor, o ato de ensinar por si só não se destaca tão facilmente da consciência de saber, necessitando para a garantia da objetividade do conhecimento apoiar-nos na psicologia da intersubjetividade, ou seja, é no momento da aplicação de um espírito a outro que avaliamos e organizamos melhor o nosso pensamento e as nossas ideias. É, portanto, bem no nível de uma relação professor/aluno, no ato mesmo de ensinar, que surgirá a pedagogia da intersubjetividade e a pedagogia dialogada, em contraposição ao ensino monolítico dos resultados e ao intelectualismo soberbo dos professores. A organização racional e coerente de uma ideia será, portanto, colocada à prova diante dessa relação intersubjetiva, donde sua coerência mediante uma discussão possibilitará descortinar suas possibilidades de clareza racional.

Bachelard diz que o desconhecimento por parte dos professores de ciências (principalmente) dos conhecimentos e experiências trazidas pelos alunos da sua vida cotidiana 
pode interferir no ensino e na aprendizagem da ciência. A este aspecto é importante atentarmos para o que diz o próprio autor.

Na educação, a noção de obstáculo pedagógico também é desconhecida. Acho surpreendente que os professores de ciências, mais do que os outros se fosse possível, não compreendam que alguém não compreenda. Poucos são os que se detiveram na psicologia do erro, da ignorância e da irreflexão [...] (BACHELARD, 2016, p. 23).

Neste caso, desconhecer o que os alunos já trazem de ideias prévias para a escola é um obstáculo pedagógico que pode dificultar o ensino de ciências, pois sendo totalmente contrário ao ensino por resultados, Bachelard vai dizer que ensinar só os resultados da ciência seria como ensinar sem oferecer dificuldades reais para os alunos, pois não existindo questionamentos, inexiste também a crítica da cultura (LOPES, 1993). Desta forma, "[...] As ilusões e os erros dos alunos permanecem; os novos conceitos apenas se imiscuem nos erros anteriores e ali ficam, conferindo a falsa impressão de aprendizagem" (LOPES, 1993, p. 326).

Bachelard critica um ensino por resultados, o qual contribui para que os alunos retenham esses resultados sem compreenderem a multiplicidade dos conceitos associados a eles. Para o autor, esse tipo de prática reforça um ensino de ciências que busca estabelecer uma relação direta entre o conhecimento científico e o conhecimento de senso comum, ou seja, o professor, na tentativa de fazer o aluno compreender o conceito e desconhecendo o que ele já traz de conhecimento prévio, induz um ensino sem complicação fazendo-o acreditar que a racionalidade do conhecimento científico é apenas um refinamento da racionalidade do senso comum, o que seria um obstáculo pedagógico dos mais perigosos de acordo com a epistemologia bachelardiana. Porém, Bachelard destaca que o professor em sua prática do racionalismo docente deve fornecer elementos para que os alunos percebam a ruptura profunda existente entre os princípios que marcam ambas as racionalidades.

A partir disso, Bachelard diz que "[...] Os professores de ciências imaginam que o espírito começa com uma aula, que é sempre possível reconstruir uma cultura falha pela repetição da lição, que se pode fazer entender uma demonstração repetindo-a ponto por ponto [...]". Para ele, esses professores "[...] Não levam em conta que o adolescente entra na aula de física com conhecimentos empíricos já constituídos: não se trata, portanto, de adquirir uma cultura experimental, mas sim de mudar de cultura experimental, de derrubar os obstáculos já sedimentados pela vida cotidiana [...] (BACHELARD, 2016, p. 23, grifos do autor). O professor deve ficar vigilante tanto em relação aos obstáculos epistemológicos como em relação aos obstáculos pedagógicos, devendo mediar o processo de ensino em busca de fazer o aluno compreender, por exemplo, a ruptura que existe entre campos 
com racionalidades distintas. É por isso que Bachelard diz que professor e aluno merecem uma psicanálise especial. E de uma maneira mais precisa ele afirma que "[...] detectar os obstáculos epistemológicos é um passo para fundamentar os rudimentos de uma psicanálise da razão" (BACHELARD, 2016, p. 24).

Na ciência, para oferecer à razão razões para evoluir, Bachelard diz que é preciso dialetizar todas as variáveis experimentais. Logo, na busca de substituir um saber fechado e estático em busca de um conhecimento aberto e dinâmico, a cultura científica deve começar por uma "catarse intelectual e afetiva" com o intuito de se colocar em "estado de mobilização permanente" (BACHELARD, 2016, p. 24). Na educação, o racionalismo docente deve se orientar com o cuidado de mobilizar-se. O professor, como mediador do ato de ensinar, deve ficar atento no ato pedagógico aos interesses envolvidos, pois a aprendizagem dos alunos acontecerá quando lhes forem dadas razões que os obriguem a mudar a sua razão (LOPES, 1993).

Bachelard enfatiza que essas observações podem ser ainda generalizadas, sendo mais visíveis no ensino de ciências, mas que se aplicam a qualquer esforço educativo. Diz ele: "[...] No decurso de minha longa e variada carreira, nunca vi um educador mudar de método pedagógico. O educador não tem o senso do fracasso justamente porque se acha um mestre. Quem ensina manda" [...]" (BACHELARD, 2016, p. 24, grifos do autor). Podemos perceber a preocupação de Bachelard sobre o professor que não tem o senso da reflexão sobre a sua prática, cultivando em si uma espécie de "alma professoral", aquela em que ele destaca um tipo de professor que se sente dono do saber, e mais do que isso, orgulhoso deste saber.

É assim, por meio de um racionalismo docente-ensinado baseado na intersubjetividade do ensino que a formação do espírito científico se dá de maneira a construir uma consciência de racionalidade. É o que nos faz crer na importância dada por ele nesta relação professor-aluno no processo intersubjetivo, em que a racionalidade orientadora desse processo (o racionalismo docente) deve refletir constantemente sobre a sua prática com o intuito de evitar erros epistemológicos e pedagógicos.

Aaprendizagem, assim entendida, é totalmente contrária à tradição escolar que coloca o ato de aprender como mera repetição de lições, correspondendo o professor àquele que ensina o conteúdo e o aluno àquele que, a partir da tarefa dada pelo professor, corresponde apreender o máximo possível do que foi ensinado, retendo os resultados e esquecendo-se da dinâmica própria da construção do objeto em seus aspectos epistemológico, cultural e social. Bachelard então diz: "A aquisição de uma forma de conhecimento se traduz automaticamente numa reforma do espírito [...]" (BACHELARD, 2009a, p. 110, grifos nosso). 
Sendo assim, Bachelard alerta para a necessidade de "uma nova pedagogia", via esta que pessoalmente lhe atraiu há vários anos.

Colocando-se contra essa pedagogia da transmissão que entende a criança como um ser que tem um cérebro inocupado, Bachelard diz que a criança "[...] nasce com um cérebro inacabado e não, como afirmava o antigo postulado da pedagogia, com um cérebro inocupado. A sociedade acaba na verdade o cérebro da criança; acaba-o através da linguagem, através da instrução, através da educação. Pode acabá-lo de diversas maneiras [...]" (BACHELARD, 2009a, p. 111, grifos do autor). Mas, segundo Bachelard, estando de acordo com uma educação de teor não-aristotélica, "dever-se-ia acabar o cérebro da criança como um organismo aberto, como o organismo das funções psíquicas abertas" (BACHELARD, 2009a, p. 111, grifos do autor).

Uma educação deve colocar a possibilidade da transformação radical do psiquismo humano, isto é, de uma reforma mental no próprio educador que se colocará numa posição de mudança e de abertura do seu próprio psiquismo, ou seja, "precisa reconhecer-se neste estado de infância cerebral" (JAPIASSÚ, 1976a, p. 74), possibilitando também na sua prática educativa uma educação para a formação do aluno que também lhe dê essa experiência de abertura e de transformação.

Para que ocorra aprendizado, não é suficiente informar o aluno de algo, comunicarIhe ideias para que ele possa respaldá-las pelo que já tem em sua mente, apenas por mera repetição. A aprendizagem reclama do ensino um estado de atenção para o que o aluno já conhece, colocando as novas ideias que estão sendo apreendidas de encontro às antigas para assim modificá-las, ocorrendo verdadeiramente a aprendizagem pela modificação do espírito do sujeito. A aprendizagem ocorre, portanto, quando as estruturas psíquicas do sujeito se modificam pelo novo conhecimento que passou por um processo de análise, discussão e modificou o seu modo de interpretar um conhecimento anterior. Ele ascendeu espiritualmente.

É necessário, no ensino, explicar a linha de produção espiritual que levou a determinado resultado para que possamos realmente ter ressonância da formação deste aluno diante dos conceitos trabalhos. O racionalismo ensinado necessita que se conheça uma noção não apenas por apresentar o seu estado atual de construção racional, mas se deve estudá-la através de seu longo percurso histórico, no qual se deu essa construção, a partir dos erros e das retificações. É preciso que se faça o aluno compreender o plano epistemológico da sua construção. Como é necessário dar razões para a própria razão evoluir, é imperativo também dar ao aluno razões para que ele aprenda que compreender é perceber que compreende. A edificação do ensino da ciência é afeita à compreensão de que os resultados são frutos de um conjunto de erros retificados. 
Lopes (2007)dizque, segundo Bachelard, para que ocorraaprendizado (especialmente nas ciências físicas) é preciso que haja mudança de cultura ${ }^{8}$, a qual é inerente ao aprendizado científico. Segundo a autora, "[...] Não é possível se adquirir nova cultura por meio da sua incorporação aos traços da remanescente. Os hábitos intelectuais incrustados no conhecimento não-questionado invariavelmente bloqueiam o processo de construção do novo conhecimento" (LOPES, 2007, p. 58). Há, assim, a recorrente necessidade de colocar todo esse passado de pensamento em estado de constante questionamento, através do contato com o novo saber. Este saber não pode se acumular ao anterior, adquirindo uma nova cultura pela simples incorporação dos traços da antiga. Antes, deve modificar a estrutura do pensamento pela aquisição de um novo saber, fruto da intersubjetividade que acontece por meio do diálogo entre professor e aluno, rompendo e superando com o que há de obstáculos epistemológicos e pedagógicos.

O psicologismo tende a se manifestar no ensino quando o professor procura explicar uma noção, por exemplo, por simples descrição e "intuição final", como diz Bachelard, ou seja, simplesmente pelo resultado em que aquela noção se encontra. Como se nota, é no ensino que se tem possibilidades de avaliar a solidez das ideias, atitude que deve estar apoiada na psicologia da intersubjetividade. É aqui também que se deve instituir o racionalismo do contra, ou seja, um racionalismo contra os erros e os obstáculos, já que o racionalismo docente está em dialética no processo intersubjetivo com espíritos variados, que carregam consigo diferentes "espectros filosóficos".

Discutindo em "O Novo Espírito Científico" o papel da mecânica não-newtoniana, Bachelard afirma que "[...] O pensamento newtoniano era de saída um tipo maravilhosamente transparente de pensamento fechado; dele não se podia sair a não ser por arrombamento" (BACHELARD, 2000, p. 43), destacando o caráter de novidade essencial das doutrinas relativísticas como um esforço de novidade total. Sem dúvida, diz Bachelard, há conhecimentos que parecem imutáveis. Crê-se, portanto, numa permanência das formas racionais como na impossibilidade de um novo método de pensamento (BACHELARD, 2000, p. 51). E o que isso tem a ver com o ensino? Acreditamos que desde que meditemos um pouco acerca do valor de abertura que o ensino deve provocar no psiquismo do aluno, tudo. "[...] Se desejamos realmente admitir que, em sua essência, o pensamento científico é uma objetivação, devemos concluir que as retificações e as extensões dele são as verdadeiras molas". É aí, segundo Bachelard, que "é escrita a história dinâmica do pensamento. É no

8 Concordamos com Lopes (2007, p. 58, em nota de rodapé) que Bachelard "não tem em sua obra maior problematização do entendimento de cultura. Por isso, nessa sua análise, a concepção de cultura acaba ficando restrita ao conjunto de concepções e valores que formam o pensamento do aluno, destituída de relações com a produção simbólica social mais ampla". 
momento em que um conceito muda de sentido que ele tem mais sentido, é então que ele é, em toda verdade, um acontecimento da conceptualização [...] (BACHELARD, 2000, p. 51, grifos do autor).

Colocando-se, portanto, do ponto de vista pedagógico, o qual, para Bachelard, se desconhece demasiadamente a importância psicológica, "[...] o aluno compreenderá melhor o valor da noção galileana de velocidade se o professor soube expor o papel aristotélico da velocidade no movimento. Prova-se assim o incremento psicológico realizado por Galileu [...] (BACHELARD, 2000, p. 51, grifos do autor). Para Bachelard, acontece exatamente o mesmo quanto à retificação dos conceitos realizada pela Relatividade, e isso demonstra a importância de fazer os alunos compreenderem a partir desse movimento de retificação que caracteriza a ciência. Compreender-se-á o valor da Relatividade se também compreenderse em que sentido ela se afasta e se aproxima da Mecânica newtoniana, por exemplo.

O ensino nessa perspectiva possibilita ao aluno experimentar a "mutação filosófica" a qual Bachelard se refere, pois, segundo o nosso autor, quem "se puser a observar-se, descobrirá certa pluralidade de filosofias associadas a uma noção rigorosa [...]" (BACHELARD, 1977 , p. 25, grifos nosso). Compreender o caminho, a pauta de cada elemento, é fazer compreender a linha de raciocínio antes mesmo de ver este raciocínio desenhado no papel. Fazer compreender a filosofia associada a cada noção para poder entender o seu amadurecimento filosófico, indo até o racionalismo eficaz, é instalar o aluno no racionalismo docente-ensinado e possibilitá-lo compreender que a ciência é uma construção permanente, e que o aprendizado é um processo oscilatório entre o ato de conhecer e o ato de desaprender para novamente conhecer, que será sempre uma busca de tornar o seu espírito um pouco mais desiludido pela renúncia dos erros, pela renúncia das suas faltas históricas.

Portanto, o papel do mestre é fazer o aluno compreender o raciocínio e o plano filosófico no estudo de uma dada noção. Indo muito além dos resultados, o campo interpsicológico instalado na relação intersubjetiva entre mestre e aluno é o diálogo e a troca de ideias. A base do racionalismo ensinado é tomada na estrutura em que este coloca-se como um valor, valor pelo qual "se vê que compreender é uma emergência do saber. O professor será aquele que faz compreender - e na cultura mais avançada em que o aluno já compreendeu - será ele quem fará compreender melhor" (BACHELARD, 1977, p. 27, grifos do autor).

\section{CONSIDERAÇÕES FINAIS}

Apesar de o pensamento de Bachelard ser mais investigado no campo do Ensino de Ciências da Natureza, esse trabalho buscou destacar contributos da epistemologia ba- 
chelardiana voltados ao campo da educação de uma maneira geral e, particularmente, da Pedagogia, destacando a ideia de uma pedagogia científica no ensino como fundamento para o desenvolvimento e a formação de um novo espírito científico. Não estando o projeto pedagógico de Bachelard desvinculado do seu projeto epistemológico, buscamos destacar que a pedagogia científica a qual o autor defende está intimamente relacionada com a sua filosofia científica a partir dos conceitos que compõem a seara do seu pensamento.

Foi possível destacar que Bachelard prefere o termo formação à educação, compreendendo o primeiro em um sentido mais amplo, a saber: uma formação que extrapola os redutos escolares, isto é, uma formação permanente. E isso se dá pelo complemente efetivo das duas vertentes do autor - a científica e a poética - pois, como observamos, Bachelard deixa transparecer a ideia de que a educação deve proporcionar a vivência do real e do irreal para uma formação mais completa, contribuindo, assim, para o desenvolvimento do sujeito.

Destacamos, também, que a aprendizagem acontece não pela soma de um conhecimento a outro, mas se dá sempre contra um saber anterior, através da retificação dos erros e da superação dos obstáculos epistemológicos. Para Bachelard, o processo de construção do conhecimento é algo próprio do sujeito, e se dá pelo processo de desarticular o próprio pensamento por meio de uma necessária e constante busca de novos conhecimentos que vêm para tornar o sujeito, uma vez mais, desenganado. Portanto, a formação do sujeito é uma via que percorre um processo ininterrupto, é constante. Ocorre através de renúncias, retificação dos erros, superação dos obstáculos, desilusão com aquilo que se julgava conhecer.

O processo pedagógico é fundamental, para Bachelard, pois é onde ocorre a relação de intersubjetividade do ensino entre professor e aluno. Ao defender um racionalismo docente-ensinado no qual ocorre a aplicação de um espírito a outro, no caso o espírito crítico (docente) ao espírito em estudo (aluno), o professor é quem deverá ajudar o aluno a descobrir que ele pode conhecer e descobrir novos saberes e, assim, mediante um intercâmbio de ideias entre ambos, conduzir o processo de ensino-aprendizagem pela via dialógica da troca de conhecimentos. O professor deve zelar pela aprendizagem do aluno, estando sempre vigilante aos obstáculos epistemológicos. A Pedagogia deve, segundo Bachelard, dizer não a um ensino que apresente apenas os resultados da ciência. O ensino deve propiciar ao aluno não só o estágio atual do conhecimento, mas propor o estudo de determinado conceito através do seu processo de desenvolvimento histórico e epistemológico. Ver-se-á, paulatinamente, como a ciência trabalha retificando ideias, conceitos, modos de agir e de pensar sobre o mundo, e que não produz verdades inquestionáveis, não obstante procura se aproximar delas. 
A Pedagogia que emana da obra de Gaston Bachelard retém um fundo pedagógico relevante para os professores, particularmente os de ciências da natureza, mas também proporciona luzes a todos os que buscam pensar em uma educação com um sentido formativo, que se baseia tanto na construção objetiva dos sujeitos, como pelo vivenciar poético que o conduza a ver o mundo sobre o olhar do cientista e do poeta. Desse modo, a educação tem papel primordial, pois isso se dá a partir da intersubjetividade entre os atores principais do processo educacional: professores e alunos. Portanto, a pedagogia científica de Bachelard, inspirada na sua epistemologia, instiga o diálogo e o debate, a dúvida, a pergunta, o desejo pela construção do saber e, particularmente, o amor pela superação das dificuldades de obtenção de um saber difícil. Daí, entendemos que a escola tornar-se-á o lócus da construção desta pedagogia da intersubjetividade entre professor e aluno, atingindo a formação do espírito científico por meio de uma pedagogia dialogada. Resumindo, uma Pedagogia da formação.

\section{REFEFÊNCIAS}

BACHELARD, Gaston. O Racionalismo Aplicado. Rio de Janeiro: Zahar, 1977 (1949). , Gaston. O Materialismo Racional. Lisboa: Edições 70, 1990 (1953).

, Gaston. A Poética do Espaço. Tradução de Antonio de Pádua Danesi; revisão da tradução Rosemary Costhek Abílio - São Paulo: Martins Fontes, 1993 (1957).

Gaston. O Novo Espírito Científico. Tradução de Juvenal Hahne Júnior $3^{\text {a }}$ ed. - Rio de Janeiro: Tempo Brasileiro, 2000 (1934).

, Gaston. O Ar e os Sonhos: Ensaio sobre a imaginação do movimento. Tradução de Antonio de Pádua Danesi - 2a ed. - São Paulo: Martins Fontes, 2001a (1943).

Gaston. A Terra e os Devaneios da Vontade: ensaio sobre a imaginação das forças. Tradução de Maria Ermantina Galvão - $2^{\mathrm{a}}$ ed. - São Paulo: WMF Martins Fontes, 2001b (1948).

, Gaston. A intuição do instante. Tradução de Antonio de Pádua Danesi Campinas - SP: Verus Editora, 2007 (1935).

, Gaston. Psicanálise do Fogo. Tradução de Paulo Neves $-3^{a}$ ed. - São

Paulo: Martins Fontes, 2008a (1938). 
, Gaston. Estudos. Tradução de Estela dos Santos Abreu. $1^{\text {a }}$ ed. - Rio de Janeiro: Contraponto, 2008b (1970).

, Gaston. A Filosofia do Não: filosofia do novo espírito científico. Tradução de Joaquim José Moura Ramos - $6^{\text {a }}$ ed. - Lisboa: Editorial Presença, 2009a. 125p (1940).

, Gaston. A Formação do Espírito Científico: contribuição para uma psicanálise do conhecimento. Tradução de Estela dos Santos Abreu. $-1^{\mathrm{a}}$ ed. $11^{\mathrm{a}}$ reimpressão, Rio de Janeiro: Contraponto, 2016 (1938).

BARBOSA, Elyana. Gaston Bachelard: o arauto da pós-modernidade - $2^{\mathrm{a}}$. Ed. - Salvador: Editora da Universidade Federal da Bahia, 1996.

Elyana. BULCÃO, Marly Bachelard: pedagogia da razão, pedagogia da imaginação. 2. ed. Petrópolis, RJ: Vozes, 2011.

BULCÃO, Marly. O racionalismo da ciência contemporânea: Introdução ao Pensamento de Gaston Bachelard. Ed. rev. e ampl. - Aparecida, SP: Ideias \& Letras, 2009.

Marly. Bachelard e Dagognet: duas perspectivas diferentes diante do binômio razão/imaginação. In: SANT'ANNA, C. (Org.); prefácio de Jean-Jacques Wunenburger. Para ler Gaston Bachelard: ciência e arte. Salvador: EDUFBA, 2010. 340p. p. 177-187.

CÉSAR, Constança Marcondes. Hermenêutica Francesa. Campinas, SP: Alínea Editora, 2015.

COSTA, Celma Laurinda Freitas. Ciência e Educação em Bachelard. Tese (doutorado em educação) - Pontifícia Universidade Católica de Goiás. Goiânia, 2015. 201 f.

CRUZ, Juliana Ferraz da. Gaston Bachelard e a formação do sujeito. Dissertação de Mestrado (2005). Goiânia - GO. Universidade Federal de Goiás - Faculdade de Educação.

DAGOGNET, François. Bachelard. Tradução de Alberto Campos - Lisboa: Edições 70, 1965.

JAPIASSÚ, H. Para ler Bachelard. Rio de Janeiro, F. Alves. 1976a , 139p.

LECOURT, Dominique. Para uma crítica da epistemologia. Lisboa: Assírio e Alvim, 1980. LOPES, A. R. C. Currículo e Epistemologia, ljuí: Ed. Unijuí, 2007. 232p.

A. R. C. As contribuições de Gaston Bachelard ao ensino de ciências. Enseñanza de las ciencias, 1993, 11 (3), 324-330. 
A. R. C. Bachelard: O Filósofo da Desilusão. Faculdade de Educação - UERJ Rio de Janeiro, Cad.Cat.Ens.Fis., v.13,n3: p.248-273, dez, 1996.

MARTINS, A. F. P. (2004) Concepções de estudantes acerca do conceito de tempo: uma análise à luz da epistemologia de Gaston Bachelard. Tese (Doutorado) São Paulo - SP; Universidade de São Paulo - USP, Faculdade de Educação - FE, Ensino de Ciências e Matemática.

PESSANHA, José Américo Motta. Vida e obra (Coleção Os pensadores). Abril Cultural São Paulo, 1978.

SILVA, I. B. Problemas pedagógicos no (im)passe de discursos sobre a produção do conhecimento científico. 2003. 225f. Tese (Doutorado em Educação) - Programa de Pós-Graduação em Educação, Universidade Federal de Santa Catarina, Florianópolis - SC, 2003.

SILVA, I. B. Inter - Relação: A pedagogia da ciência: uma leitura do discurso epistemológico de Gaston Bachelard. $2{ }^{\text {a }}$ ed. - ljuí - Ed. Unijuí, 2007. - 176 p. - (Coleção fronteiras da educação).

WUNENBURGER, Jean-Jacques. O pensamento renano de Gaston Bachelard: conflito ou aliança da razão e da imaginação? Cronos, Natal-RN, v. 4, n. 1/2, p. 15-22, jan./dez. 2003.

WUNENBURGER, Jean-Jacques. Bachelard e a sedução dialética. In: SANT'ANNA, C. (Org.). Para ler Gaston Bachelard: ciência e arte. Salvador: EDUFBA, 2010. 